\title{
OPTIMIZATION OF ULTRASONICALLY ASSISTED ADSORPTION OF Cu(II) ON CARBONIZED AND ACTIVATED WALNUT SHELLS
}

UDC 620.179.16.662.71:519.233.5

\author{
Dragan Milenković ${ }^{1}$, Milutin Milosavljević ${ }^{2}$, Aleksandar Bojić3 \\ ${ }^{1}$ High Technological Technical School Kruševac, 37000 Kruševac, Serbia \\ ${ }^{2}$ Faculty of Technical Science, University of Priština, Kosovska Mitrovica, Serbia \\ ${ }^{3}$ Faculty of Science and Mathematics, University of Niš, Niš, Serbia
}

\begin{abstract}
The effects of ultrasound (US) on the adsorption process of $\mathrm{Cu}(\mathrm{II})$ on granulated activated carbon (GAC), produced by walnut shells, was studied in this paper. Equilibrium results of the adsorption process are tested by Freundlich and Langmuir adsorption isotherms, and their linearization and determination of model parameters $k ; n ; b$ and Qo. The adsorption capacity of GAC is 1.7 to $3.86 \mathrm{mmol} / \mathrm{g}$ with the use of US, and 0.66 to $2.7 \mathrm{mmol} / \mathrm{g}$ without the use of US. The increase of specific surface and initial concentration increase the efficacy of adsorption. Acquired mathematical regression equations very well represent experimental results, and the correlation coefficient $(R 2)$ is greater than 0.993.
\end{abstract}

Key words: active carbon, ultrasound, regression analysis

\section{INTRODUCTION}

Ultrasound has already found numerous applications in the field of physicochemical process. The examples for that are numerous: extraction [1,2,3], dissolution $[4,5,6]$, adsorption [7,8,9], crystallization [10]. The major phenomenon responsible for this is cavitation $[11,12,13]$. Through a series of compression and expansion cycles created by acoustic waves, gas bubbles in the liquid may grow larger than $100 \mu \mathrm{m}$. The bubbles eventually become unstable and implode producing high-speed micro-jets of liquid, intense localized heating and high-pressure shock waves [14]. Cavitation causes extreme effects locally, such as liquid jets of up to $280 \mathrm{~m} / \mathrm{s}$, pressures of up to 2000 bar and temperatures of up to $5000{ }^{\circ} \mathrm{C}$. Because of that US improves mass transport in gas and liquid systems.

Received February 20, 20187 / Accepted April 13, 2018

Corresponding author: Dragan Milenković

High Technological Technical School Kruševac, Kosančićeva 36, 37000 Kruševac, Serbia

E-mail: dragan956@gmail.com 
Activated carbon $(\mathrm{AC})$ is produced by carbonization process and various activations of organic materials $[15,16,17]$. The structure characteristics of the obtained AC are the result of nature of the used material and parameters of activation technique [18]. Adsorption characteristics are effects of their structure and basic role in high adsorption performance of $\mathrm{AC}$ is given to high surface area and porosity. According to IUPAC classification, all pores are classified in three groups according to a diameter [19].

The micro pore structure represents unexploited resource, because diffusion process dominantly happens in them during the adsorption [20]. Mechanism research of inner diffusion mass transfer during the adsorption, studied by Koganovskii et al. [21] shows that using of US can have positive effect on this process [22,23,24,25]. However, mass transfer process during the adsorption, happens in two stages. In the first stage, the molecules of adsorbate diffuse from solution to outer surface of adsorbents particle. In the second stage, the molecules of adsorbate diffuse through canals-pores with different diameter. Resulting sorption process rate is limited by slower stage. Providing the appropriate conditions with intensive solution mixing can disregard diffusion of the adsorbate from solution to an adsorbent surface. Therefore, adsorbent porous structure volume has crucial influence on speed of adsorbate in the adsorbent interior. This way, filling the micro pores volume, is performed exclusively by adsorbed molecules diffusion in a micro pore interior while adsorbent diffusion depends on two concentration gradient: solution concentration gradient that fills the pores, from $\mathrm{c}=\mathrm{f}(\mathrm{x}, \mathrm{y}, \mathrm{z}, \tau)$, adsorbent concentration gradient in solution $\mathrm{a}=\mathrm{f}(\mathrm{x}, \mathrm{y}, \mathrm{z}, \tau)[21]$.

It is very difficult to describe such a complex porous structure condition and also very complex adsorption process. Because of that, there are a large number of models that describe with a greater or lesser success the state of the adsorption equilibrium and the kinetics of the adsorption process. In this direction, Langmuir suggested a theory to describe monolayer adsorption on homogeneous surfaces [26]. In 1906, Freundlich suggested a model to describe the adsorption properties heterogeneous systems [27]. A very popular isotherm was suggested by Redlich and Peterson [28]. This isotherm combines the Langmuir and Freundlich isotherm.

If there is an insufficient exact theoretical knowledge for mathematical description of the investigated process, it is most suitable to use empirical models acquired by methods of mathematical planning of experiment and regression analysis [29,30,31]. By that, mathematical model is being formed by correlation of input output parameters of process, not considering the mechanism of observed process. In general case during the research of any physico-chemical process, mathematical model of equation which describes influence of parameters of process, that is, independent variables on the response function is shown in a form: mathematical model of linear or nonlinear type with line factor effects or, mathematical model of linear or nonlinear type with factors interaction.

In an investigated process, an attempt to establish regression model with line factor effects was made, which connects maximal adsorption (q) with specific surface GAC (S) and starting concentrations $\mathrm{Cu}(\mathrm{II})\left(\mathrm{C}_{\mathrm{o}}\right)$ of general form:

$$
q=\mathrm{f}\left(S ; C_{o}\right)
$$

and with interaction of line factor effects of investigated process:

$$
q=\mathrm{f}\left(S ; C_{o} ; S \cdot C_{o}\right)
$$


In regression form models, (1) and (2) mostly have a form in shape of power function, respectively [18]:

$$
\begin{gathered}
q=p_{o} \cdot S^{p_{1}} \cdot C_{o}^{p_{2}} \\
q=p_{o} \cdot S^{p_{1}} \cdot C_{o}^{p_{2}} \cdot e^{\left(p_{12} \ln S \cdot \ln C_{0}\right)}
\end{gathered}
$$

The topic of this research was the development of the method for obtaining GAC from walnut granules. The aim of the study was to examine the effect of US on adsorption of $\mathrm{Cu}(\mathrm{II})$ on GAC, comparing relevant parameters in Freundlich and Langmuir theoretical models, and to set the mathematical model of dependence, equilibrium adsorption $\left(q_{\mathrm{e}}\right)$ from the initial concentration $\left(C_{\mathrm{o}}\right)$ and the specific surface area $(S)$ of the GAC.

\section{EXPERIMENTAL PART}

\subsection{Materials}

Walnut (domestic Serbian variety "Šampion") shells were supplied from the central part of Serbia. Fresh walnut shells were washed several times with distilled water to remove surface impurities, dried at $100{ }^{\circ} \mathrm{C}$ overnight, crushed by a hammer mill and then simultaneously carbonized in inert argon atmosphere and activated by water steam in a rotary oven at $750 \pm 5{ }^{\circ} \mathrm{C}$ for $2 \mathrm{~h}$.

$\mathrm{Cu}(\mathrm{II})$ acetate, analytical reagent grade, was purchased from Merck Co. Distilled water was used to prepare aqueous solutions of $\mathrm{Cu}(\mathrm{II})$ acetate.

In the study, we obtained three species of GAC (A, B, and C) of different structure characteristics with specific surfaces $933 ; 1236$; and $1442 \mathrm{~m}^{2} / \mathrm{g}$, respectively. Characteristics of attained GAC have been analyzed by standard methods are shown in Table 1.

\begin{tabular}{|c|c|c|c|c|}
\hline \multirow{2}{*}{$\begin{array}{l}\text { Characteristics } \\
\text { GAC }\end{array}$} & \multirow{2}{*}{ Method } & \multicolumn{3}{|c|}{ Species GAC } \\
\hline & & $\mathrm{A}$ & $\mathrm{B}$ & $\mathrm{C}$ \\
\hline Specific surface $\left[\mathrm{m}^{2} / \mathrm{g}\right]$, & ISO 18757:2003 & 1442 & 1236 & 933 \\
\hline Iodine number $[\mathrm{mg} / \mathrm{g}]$ & ASTM D4607 & 1464 & 1244 & 943 \\
\hline Index metilen blue $\left[\mathrm{cm}^{3}\right]$ & ASTM C837 & 17.4 & 14.7 & 9.9 \\
\hline Volume of micro-pores $\left[\mathrm{cm}^{3} / \mathrm{g}\right]$ & & 0.68 & 0.56 & 0.44 \\
\hline Volume of mezzo-pores $\left[\mathrm{cm}^{3} / \mathrm{g}\right]$ & ASTM D4284 & 0.51 & 0.44 & 0.33 \\
\hline Volume of macro-pores $\left[\mathrm{cm}^{3} / \mathrm{g}\right]$ & & 0.23 & 0.19 & 0.14 \\
\hline
\end{tabular}

Table 1 Physico-mechanical properties of GAC

\subsection{Batch adsorption experiments}

Adsorption of $\mathrm{Cu}$ (II) on the GAC was performed with $5 \mathrm{~g}$ of $\mathrm{GAC}$ in $0.250 \mathrm{~L}$ solution with various predetermined concentrations. Initial concentrations $\mathrm{Cu}$ (II) used in experiment were $0.3 ; 0.2 ; 0,1 ; 0.05$; and $0,025 \mathrm{~mol} / \mathrm{L}$. Two experiments were made in isothermal conditions. In the first of the experiments, sorption process was performed with the continual solution mixing with a magnetic mixer. In the second experiment, performed simultaneously, dish with a solution of the same concentration and GAC was in the US waves field. Ultrasound effects was obtained in a dish in US bath. Applied frequency of the US waves in 
US bath was $40 \mathrm{kHz}$. The time of contacting needed to reach equilibrium, was 90 minute. Equilibrium $\mathrm{Cu}$ (II) concentration was determined by AAS (Perkin-Elmer 1100B). The $\mathrm{Cu}(\mathrm{II})$ mass per mass unit of GAC, $\left(q_{\mathrm{e}}\right)$ was determined based on concentration difference in a observed time interval and work solution volume using the formula:

$$
q=V\left(C_{o}-C_{r}\right) / m_{G A C}
$$

Results of fitting experimental data by Freundlich and Langmuir models are shown in the table and in graphic. In Table 2 are shown the values of parameters Freundlich (5) and Langmuir (6) models of adsorption isotherms:

$$
\begin{gathered}
q_{e}=k \cdot C_{o}{ }^{1 / n} \\
q_{e}=\frac{Q_{\mathrm{o}} \cdot b \cdot C_{\mathrm{o}}}{1+b \cdot C_{\mathrm{o}}}
\end{gathered}
$$

by their linearization into forms (7) and (8), respectively

$$
\begin{aligned}
& \ln q_{e}=\ln k+\frac{1}{n} \ln C_{\mathrm{o}} \\
& \frac{1}{q_{e}}=\frac{1}{Q_{o}}+\frac{1}{b \cdot Q_{o}} \cdot \frac{1}{C_{o}}
\end{aligned}
$$

By graphical presenting of paired points $\ln q_{\mathrm{e}}=\mathrm{f}\left(\ln C_{\mathrm{o}}\right)$ that is, $1 / q_{\mathrm{e}}=\mathrm{f}\left(1 / C_{\mathrm{o}}\right)$ parameters are calculated on the bases of gradient and segment of formed line.

\section{3. RESULTS AND DISCUSSION}

Results of testing of experimental data by Freundlich model indicate the satisfactory accordance in the scope of applied concentrations. Parameters of Freundlich model $k$, and $1 / n$ indicate proper trend of growing with increasing specific surface of adsorbents. This fact is in accordance with physical sense of parameters $k$ and $1 / n$ as with their concept that they represent rough measurement adsorption capacity, that is, intensity. The parameter of intensity of Freundlich isothermal ( $1 / n)$ grows from 0.117 to 0.516 , without US, and 0.500 to 0.797 , with US, with a rise in the specific surface, respectively. An increase of an adsorption intensity, with the application of US to all GAC (A, B, C), is observed.

The value of parameters of Langmuir models: $Q_{\mathrm{o}}$ which represents the mass of adsorptive per unit mass of adsorbents when monomolecular layer of adsorptive are formed on it, and b- which is dependant of change of enthalpy of adsorption, are in line with expectations. The monomolecular capacity $Q_{\mathrm{o}}$ increases in range $0.6 \mathrm{mmol} / \mathrm{g}$ to 2.7 $\mathrm{mmol} / \mathrm{g}$ without US and $1.7 \mathrm{mmol} / \mathrm{g}$ to $3.86 \mathrm{mmol} / \mathrm{g}$ with US when the specific surface area increases, respectively. An increase of an adsorption capacity with the application of US to all GAC (A, B, C), is observed. 
The Mathematical model of dependence equilibrium adsorption $\left(q_{\mathrm{e}}\right)$, from specific surface $\mathrm{GAC},(S)$ and starting concentration $\mathrm{Cu}(\mathrm{II}),\left(C_{\mathrm{o}}\right)$, is established by the use of methods of mathematical planning of experiment and regression analysis. A complete factorial plan of experiment with three repetitions in zero point has been applied. Data about values of process parameters used in an experiment that are relevant for setting up mathematical models, are shown in Table 3 with starting concentrations 0,$3 ; 0,1$; and $0,025 \mathrm{~mol} / \mathrm{L}$.

Table 2 Comparative preview of theoretical models parameters of adsorption isotherms for $\mathrm{Cu}$ (II) on different GAC without and with use of US

\begin{tabular}{cccccccc}
\hline & \multicolumn{4}{c}{ Without the US } & \multicolumn{3}{c}{ With the US } \\
\cline { 2 - 8 } Langmuir & $S, \mathrm{~m}^{2} / \mathrm{g}$ & $Q_{0}, \mathrm{~mol} / \mathrm{g}$ & $b, \mathrm{~L} / \mathrm{mol}$ & $\mathrm{R}^{2}$ & $Q_{0}, \quad \mathrm{~mol} / \mathrm{g}$ & $b, \mathrm{~L} / \mathrm{mol}$ & $\mathrm{R}^{2}$ \\
\hline \multirow{5}{*}{ Freundlich } & 1442 & 0.00270 & 8.480 & 0.982 & 0.00386 & 6.250 .995 \\
& 1236 & 0.00210 & 10.560 & 0.996 & 0.0026 & 7.640 .993 \\
& 933 & 0.00066 & 66.600 & 0.975 & 0.0017 & 11.260 .989 \\
\cline { 2 - 9 } & 1442 & $k,(\mathrm{~mol} / \mathrm{g}) /(\mathrm{mol} / \mathrm{L})^{\mathrm{n}}$ & $1 / n$ & $\mathrm{R}^{2}$ & $k,(\mathrm{~mol} / \mathrm{g}) /(\mathrm{mol} / \mathrm{L})^{\mathrm{n}}$ & $1 / n$ & $\mathrm{R}^{2}$ \\
& 1236 & 0.00380 & 0.516 & 0.973 & 0.0052 & 0.7970 .988 \\
& 933 & 0.00267 & 0.431 & 0.968 & 0.00373 & 0.7230 .985 \\
\hline
\end{tabular}

Table 3 Plan of matrix for complete experiment with three repetitions in zero point for two-factor model

\begin{tabular}{cccccccccr}
\hline \multirow{2}{*}{$\begin{array}{c}\mathrm{N}^{\mathrm{o}} \\
\text { exp. }\end{array}$} & \multicolumn{4}{c}{ Coding values } & \multicolumn{2}{c}{ Native values } & \multicolumn{2}{c}{$\begin{array}{c}\text { Experimental values with } \\
\text { use of US }\end{array}$} & \multicolumn{2}{c}{$\begin{array}{c}\text { Experimental values } \\
\text { without use of US }\end{array}$} \\
\cline { 2 - 11 } & $\mathrm{X}_{1}$ & $\mathrm{X}_{2}$ & $\mathrm{X}_{1} \mathrm{X}_{2}$ & $\begin{array}{c}S \\
{\left[\mathrm{~m}^{2} / \mathrm{g}\right]}\end{array}$ & $\begin{array}{c}C_{\mathrm{o}} \\
{[\mathrm{mol} / \mathrm{L}]}\end{array}$ & $\begin{array}{c}q \\
{[\mathrm{mmolCu} / \mathrm{g}]}\end{array}$ & $\mathrm{Y}=\ln q$ & $\begin{array}{c}q \\
{[\mathrm{mmolCu} / \mathrm{g}]}\end{array}$ & $\mathrm{Y}=\ln q$ \\
\hline 1. & +1 & +1 & +1 & 1442 & 0,3 & 2.154 & 0,7670 & 1.829 & 0,6037 \\
2. & +1 & -1 & -1 & 1442 & 0,025 & 0,504 & $-0,6840$ & 0,450 & $-0,4005$ \\
3. & -1 & +1 & -1 & 933 & 0,3 & 1,282 & 0,2480 & 1,086 & 0,0823 \\
4. & -1 & -1 & +1 & 933 & 0,025 & 0,369 & $-0,996$ & 0,313 & $-1,1605$ \\
5. & 0 & 0 & 0 & 1236 & 0,1 & 1,077 & 0,0741 & 0.917 & 0,0869 \\
6. & 0 & 0 & 0 & 1236 & 0,1 & 1,095 & 0,0901 & 0,872 & $-0,1367$ \\
7. & 0 & 0 & 0 & 1236 & 0,1 & 1,077 & 0,0741 & 0.903 & $-0,1016$ \\
\hline
\end{tabular}

\subsection{Regression model with use of US}

On the bases of equations 1 to 4 , for investigation adsorption with use of US, regression model $q=\mathrm{f}\left(S, C_{o}\right)$ is established in form:

$$
q=3,89 \cdot 10^{-3} \cdot S^{0,97} \cdot C_{0}^{0,57}
$$

whose coefficient of correlation for mathematical model (9) is $R=0.973$. Graphical interpretation of regression model (9) is shown in Figure 1. 


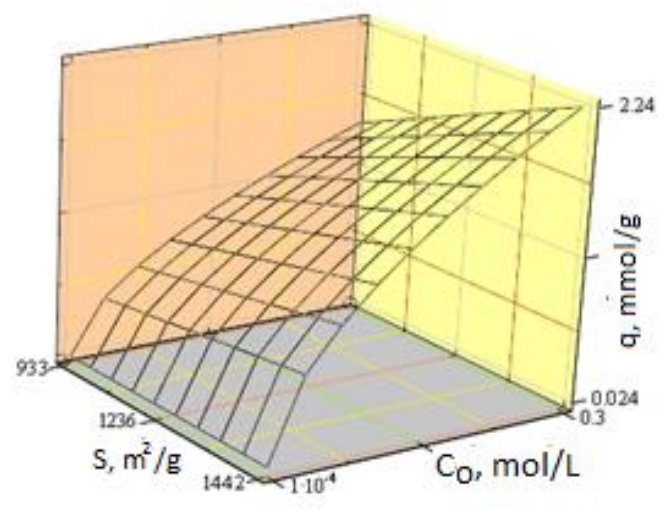

Fig. 1 Graphic interpretation of model $q=\mathrm{f}\left(S, C_{o}\right)$ equation (9)

Regression equation in native coordinate with interaction separate factors $q=\mathrm{f}\left(S, C_{o}, S \cdot C_{o}\right)$ has a form:

$$
q=1,25 \cdot 10^{-4} \cdot S^{1,45} \cdot C_{0}^{-0,89} \cdot \mathrm{e}^{0,2 \cdot \ln S \cdot \ln \mathrm{C}_{0}}
$$

which coefficient of correlation for mathematical model (10) is $R=0,975$. Graphical interpretation of mathematical model (10) is shown in Figure 2.

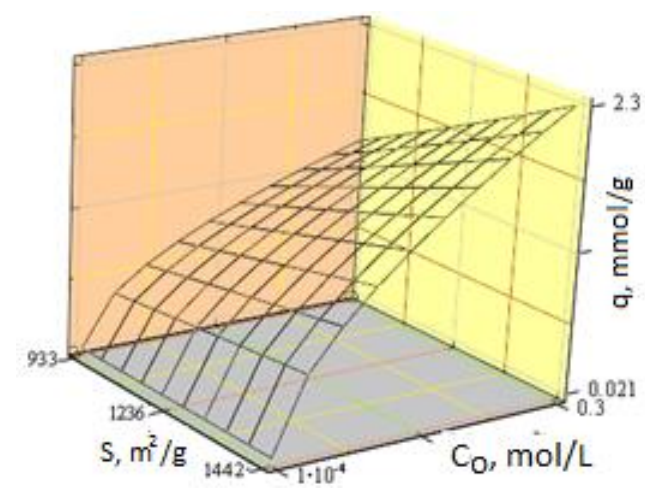

Fig. 2 Graphic interpretation model $q=\mathrm{f}\left(S, C_{o}, S \cdot C_{o}\right)$ equation (10)

\subsection{Regression model without use of US}

On the bases of equations 1 to 4 , for investigation adsorption without use of US, regression model $q=\mathrm{f}\left(S, C_{\mathrm{o}}\right)$ is established in form:

$$
q=4,86 \cdot 10^{-3} \cdot S^{0,92} \cdot C_{\mathrm{o}}^{0,58}
$$

whose coefficient of correlation for mathematical model (11) is $R=0,973$. Graphical interpretation of mathematical model (11) is shown in Figure 3. 


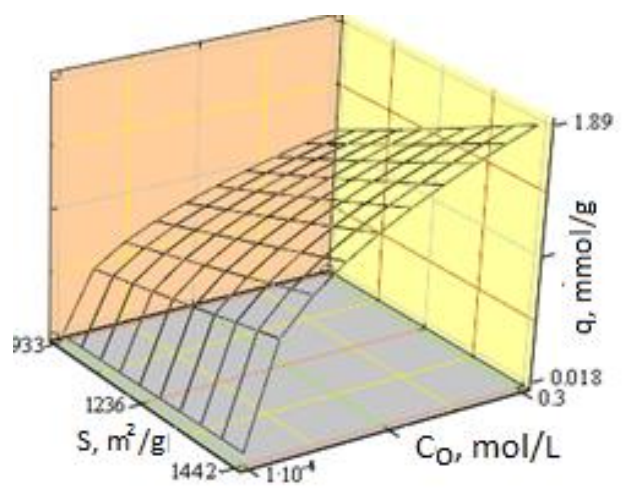

Fig. 3 Graphic interpretation of $q=\mathrm{f}\left(S, C_{\mathrm{o}}\right)$ equation (11)

Regression equation in native coordinate with interaction separate factors, $q=\mathrm{f}\left(S ; C_{o} ; S \cdot C_{\mathrm{o}}\right)$ has a form:

$$
q=6,95 \cdot 10^{-5} \cdot S^{1,51} \cdot C_{o}^{-1,21} \cdot e^{0,25 \cdot \ln S \cdot \ln C_{o}}
$$

whose coefficient of correlation for mathematical model (12) is $\mathrm{R}=0,976$. Graphical interpretation of mathematical model (12) is shown in Figure 4.

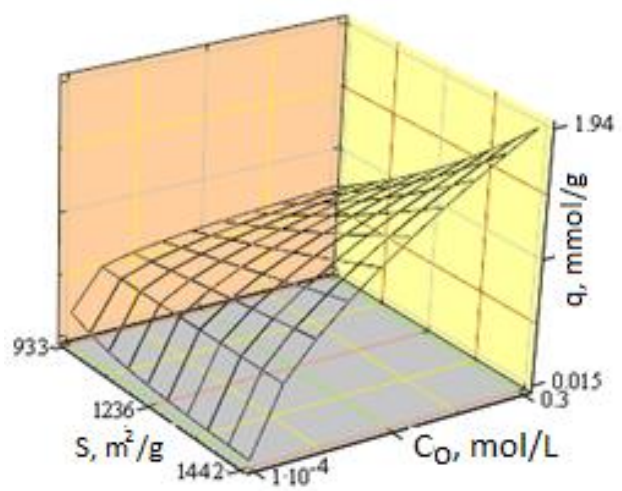

Fig. 4 Graphic interpretation of model $q=\mathrm{f}\left(S, C_{o}, S \cdot C_{\mathrm{o}}\right)$ equation (12)

On the bases of coefficient of correlation values for established mathematical models, without doubt it can be claimed that in both cases, with the use and without the use of US, both types of models with interaction of separate factors (9) and (12) adequately represent the experimental results. 


\section{CONCLUSIONS}

Based on the obtained results in this study, the following conclusions can be made:

- Active carbon obtained from the walnut shell has a distinguished developed porous structure with noticeable share of micro porous structure;

- The investigated $\mathrm{Cu}(\mathrm{II})$ adsorption to GAC, obtained from shell walnuts, can be fully described by the Freundlich and Langmuir models;

- The use of US has a positive effects on $\mathrm{Cu}(\mathrm{II})$ adsorption capacity and intensity;

- The maximal monomolecular capacity $Q_{0} 2.7 \mathrm{mmol} / \mathrm{g}$, without US and at 3.86 $\mathrm{mmol} / \mathrm{g}$ with US, was obtained.

- Mathematical models obtained by regression analysis with interaction of separate factors and on the bases of criteria parameters $\mathrm{R}^{2}$ can be used during the design of adequate adsorption systems.

The results obtained in this paper point to the need for more detailed impact studies and other parameters that influence the adsorption process, first of all: the influence of particle size, adsorbent doses, temperature, $\mathrm{pH}$, morphology of the GAC obtained, GAC surface structure, carbonization and activation parameters, etc.

Acknowledgement: This work was financed by the Serbian Ministry of Education, Science, and Technological Development through the Grant TR34008.

\section{REFERENCES}

1. F. Chemat, N. Rombaut, A.G. Sicaire, A. Meullemiestre, A.S. F. Tixier, M. Abert-Vian, Ultrasound assisted extraction of food and natural products. Mechanisms, techniques, combinations, protocols and applications. A review, Ultrasonics Sonochemistry, 34 (2017) 540-560. doi:10.1016/j.ultsonch.2016.06.035

2. I.T. Stanisavljević, M.L. Lazić, V.B. Veljković, Ultrasonic extraction of oil from tobacco (Nicotiana tabacum L.) seeds, Ultrasonics Sonochemistry 14(5) (2007) 646-652. doi:10.1016/j.ultsonch.2006.10.003

3. D.T. Veličković, D.M. Milenović, M.S.Ristić, V.B. Veljković, Kinetics of ultrasonic extraction of extractive substances from garden (Salvia officinalis L.) and glutinous (Salvia glutinosa L.) sage Ultrasonics Sonochemistry 13 (2006) 150. doi:10.1016/j.ultsonch.2005.02.002

4. A.V.Beșe, Effect of ultrasound on the dissolution of copper from copper converter slag by acid leaching,Ultrasonics Sonochemistry 14 (2007) 790. doi:10.1016/j.ultsonch.2007.01.007

5. T.Tekin, D.Tekin, M.Bayaramoglu, Effect of ultrasound on the dissolution kinetics of phosphate rock in HNO3, Ultrasonics Sonochemistry 8 (2001) 373. doi:10.1016/S1350-4177(00)00078-X

6. H. Okur, T. Tekin, A.K. Ozer, M. Bayaramoglu, Effect of ultrasound on the dissolution of colemanite in H2SO4, Hydrometallurgy 67 (2002) 79. doi:10.1016/S0304-386X(02)00137-8

7. D.D. Milenković, P.V. Dašić, V.B. Veljković, Ultrasound-assisted adsorption of Cu(II) ions on hazelnut shell activated carbon, Ultrasonics Sonochemistry 16 (4) (2009) 557-563. doi:10.1016/j.ultsonch.2008.12.002

8. D.D. Milenković, A.Lj. Bojić, V.B. Veljković, Ultrasound-assisted adsorption of 4-dodecylbenzene sulfonate from aqueous solutions by corn cob activated carbon, Ultrasonics Sonochemistry, 20(3) (2013) 955-962. doi:10.1016/j.ultsonch.2012.10.016

9. Kostić M., Mitrović J., Radović M., Đorđević M., Petović M., Bojić D., Bojić A., Effects of power of ultrasound on removal of $\mathrm{Cu}(\mathrm{II})$ ions by xanthated Lagenaria vulgaris shell, Ecological Engineering, 90 (2016) 82-86. doi:10.1016/j.ecoleng.2016.01.063

10. M. D. L. De Castro, F. P. Capote, Ultrasound assisted crystallization (Sonocrystallization), Ultrason. Sonochem.14 (2007) 717-724. doi:10.1016/j.ultsonch.2006.12.004

11. T. Lepoint; F. MullieWhat exactly is cavitation chemistry?, Ultrasonics Sonochemistry 1(1) (1994)S13 doi:10.1016/1350-4177(94)90020-5

12. S.L. Peshkovsky, A.S. Peshkovsky, Shock-wave model of acoustic cavitation Ultrasonics Sonochemistry15(4) (2008) 618. doi:10.1016/j.ultsonch.2007.07.006 
13. C. Virone, H. J. M. Kramer, G. M. van Rosmalen, A. H. Stoop, T. W. Bakker, Primary nucleation induced by ultrasonic cavitation, J. Cryst. Growth 294 (2006) 9-15. doi:10.1016/j.jcrysgro.2006.05.025

14. AK.Suslick, N. Eddingsaas, D. Flannigan, S. Hopkins, H. Xu, Extreme conditions during multi-bubble cavitation: Sonoluminescence as a spectroscopic probe, Ultrasonics Sonochemistry18 (4) (2011) 842-846. doi:10.1016/j.ultsonch.2010.12.012

15. E. Sharifpour, H.Z. Khafri, M. Ghaedi, A. Asfaram, R. Jannesar, Isotherms and kinetic study of ultrasound-assisted adsorption of malachite green and $\mathrm{Pb} 2+$ ions from aqueous samples by copper sulfide nanorods loaded on activated carbon: Experimental design optimization, Ultrasonics Sonochemistry, 40 Part A, (2018) 373-382. doi:org/10.1016/j.ultsonch.2017.07.030

16. D. Bojic, M. Momcilovic, D. Milenkovic, N.Velinov, J. Mitrovic, P. Bankovic, G. Nikolic Characterisation of a low cost Lagenaria Vulgaris based Carbon for ranitidine removal from aqueous solutions, Arabian Journal of Chemistry, 10(7) (2016) 956-964.doi:10.1016/j.arabjc.2014.12.018

17. N.A. Fakhre, B.M. Ibrahim, The use of new chemically modified cellulose for heavy metal ion adsorption, Journal of Hazardous Materials, 343 (2018) 324-331. doi:10.1016/j.jhazmat.2017.08.043

18. S. F. Grebennikov, T. V. Smotrina, T. A. Ananeva, A. Yu. Kuznetsov, Porous Structure of Composites, Russian Journal of Applied Chemistry78(6) (2005) 985-988.doi:10.1007/s11167-005-0433-6

19. IUPAC, Manual of Simbols and Terminology, Appendix 2, Pt. 1, Colloid and Surface Chemistry, Pure Applied Chemistry, 31, 1972, p. 578

20. Milenkovic D.D.; Stoiljkovic S.T.; Ilic D.R., Determination of the structural and chemisorption characteristics of granulated active charcoal on the basis of coconut sheell. Chemical Industry, 58(9)(2004) 416-422. http://www.ache.org.rs/HI/

21. KoganovskiiA.M; LevchnkoT.M.; Roda I.G. M., Maaruttoovskkii R.M., Adsorpcionaya tehnologiya ochistki stochnyh vod. Moskva: Tehnika, 1981

22. Sayan E., Chemical Engineering Journal, 115, Issue 3, 2006, p. 213. doi:10.1016/j.cej.2005.09.024

23. A.C. Fröhlich, R. Ocampo-Pérez, V. Diaz-Blancas, N.P.G. Salau, G.L. Dotto, Three-dimensional mass transfer modeling of ibuprofen adsorption on activated carbon prepared by sonicatio, Chemical Engineering Journal, (341) 2018，65-74. doi:10.1016/j.cej.2018.02.020

24. Gáplovský A., Gáplovský M., Kimura T., Toma Š., Donovalova J. Vencel T., Ultrason. Sonochemical, 14, 2007, p. 695. doi:10.1016/j.ultsonch.2006.10.005

25. H. Wang, R. Xie, J. Zhang, J. Zhao, Preparation and characterization of distillers' grain based activated carbon as low cost methylene blue adsorbent: Mass transfer and equilibrium modeling, Advanced Powder Technology, 29(1) ( 2018) 27-35.

26. I. Langmuir,. J. Am. Chem. Soc. 40(1918) 136

27. Z.H. Freundlich,. Phys. Chem. 57 (1906) 385

28. B.O. Redlich, D.L. Peterson, J. Phys. Chem. 63 (1959) 1024

29. Kostić M., Đorđević M., Mitrović J., Velinov N., Bojić D., Antonijević M., Bojić A., Removal of cationic pollutants from water by xanthated corn cob: optimization, kinetics, thermodynamics, and prediction of purification process, Environmental Science and Pollution Research, 24(21) (2017) 17790-17804.

30. Andreea Gabor, Corneliu Mircea Davidescu, Adina Negrea, Mihaela Ciopec, Narcis Duteanu Optimizing the lanthanum adsorption process onto chemically modified biomaterials using factorial and response surface design, Journal of Environmental Management, 204(3) (2017) 839-844. doi:10.1016/j.jenvman.2017.01.046

31. F.M. Y1lmaz, M.Karaaslan, H. Vardin, Optimization of extraction parameters on the isolation of phenolic compounds from sour cherry (Prunus cerasus L.) pomace, J Food Sci Technol. 52(5) (2015) 2851-2859. doi:10.1007/s13197-014-1345-3 


\section{OPTIMIZACIJA ULTRAZVUČNO PODPOMOGNUTE ADSORPCIJE Cu(II) NA KARBONIZOVANIM I AKTIVIRANIM LJUSKAMA ORAHA}

U radu su prikazani rezultati uticaja ultrazvuka na proces adsorpcije Cu(II) jona na granulisanom aktivnom uglju (GAC) proizvedenom od orahovih ljuski. Rezultati dobijeni tokom procesa adsorpcije testirani su pomoću Freundich i Langmuir modela adsorpcionih izotermi,a parametri modela: $k ; n ; b i Q_{0}$, određeni su njihovom linearizacijom. Matematički modeli koji koreliraju ravnotežnu adsorpciju (q) sa specifičnim površinom GAC (S) i početnim koncentracijama $\mathrm{Cu}(\mathrm{II})\left(\mathrm{C}_{\mathrm{o}}\right)$ određeni su matematičkim planiranjem eksperimenta i regressionom analizom. Dobijeni rezultati ukazuju na doprinos upotrebe ultrazvuka tokom adsorpcije $\mathrm{Cu}(\mathrm{II})$ iz vodenog rastvora. Veličina specifične površine i početne koncentracije ima pozitivan uticaj na veličinu adsorpcione ravnoteže. Dobijeni matematičkimodeli vrlo dobro prate eksperimentalne rezultate.

Ključne reči: Aktivni ugalj, ultrazvuk, regressiona analiza 